\title{
Correction to: Biobanks and Individual Health Related Findings: from an Obstacle to an Incentive
}

\author{
Jurate Lekstutiene $^{1}$ D . Søren Holm ${ }^{2,3} \cdot$ Eugenijus Gefenas $^{1}$
}

Accepted: 28 September 2021 / Published online: 19 October 2021

(C) The Author(s) 2021

\section{Correction to: Science and Engineering Ethics (2021) 27:55 https://doi.org/10.1007/s11948-021-00330-9}

The article "Biobanks and Individual Health Related Findings: from an Obstacle to an Incentive", written by Jurate Lekstutiene, Søren Holm and Eugenijus Gefenas was originally published Online without Open Access. After publication in volume 27, issue 4, page 1-16 the author decided to opt for Open Choice and to make the article an Open Access publication. Therefore, the copyright of the article has been changed to (C) The Author(s) 2021 and the article is forthwith distributed under the terms of the Creative Commons Attribution 4.0 International License.

This article is licensed under a Creative Commons Attribution 4.0 International License, which permits use, sharing, adaptation, distribution and reproduction in any medium or format, as long as you give appropriate credit to the original author(s) and the source, provide a link to the Creative Commons licence, and indicate if changes were made. The images or other third party material in this article are included in the article's Creative Commons licence, unless indicated otherwise in a credit line to the material. If material is not included in the article's Creative Commons licence and your intended use is not permitted by statutory regulation or exceeds the permitted use, you will need to obtain permission directly from the copyright holder. To view a copy of this licence, visit http://creativecommons.org/licen ses/by/4.0.

The original article has been corrected.

The original article can be found online at https://doi.org/10.1007/s11948-021-00330-9.

Jurate Lekstutiene

jurate.lekstutiene@gmail.com

1 Institute of Health Sciences, Faculty of Medicine, Vilnius University, M.K. Čiurlionio 21, 03101 Vilnius, Lithuania

2 Centre for Social Ethics and Policy, School of Law, University of Manchester, Manchester, UK

3 Center of Medical Ethics, Institute of Health and Society, Faculty of Medicine, University of Oslo, Oslo, Norway 
Publisher's Note Springer Nature remains neutral with regard to jurisdictional claims in published maps and institutional affiliations. 